\title{
Abreviaturas del poder porfirista en el espacio urbano hermosillense
}

Andrés Abraham Gutiérrez C.

Resumen: en el presente artículo se ofrece una interpretación sobre el ejercicio del poder por parte del Estado y la elite durante el porfiriato a través del espacio urbano, en ese sentido se rescatan las funciones simbólicas que cumplieron los equipamientos de la ciudad de Hermosillo durante dicho periodo. Se retoman tres tipos de fenómenos cohesionadores de la misma índole, a fin de validar el supuesto de que la nomenclatura de las calles de Hermosillo es un elemento cohesionador y generador de una conciencia patriótica y nacionalista, desde la perspectiva del panoptismo de Michel Foucault; la estatuomanía, obsesión de la época por generar monumentos para promover los valores liberales, y la invención de la tradición, propuesta de Eric Hobsbawm, aplicada a los rituales cívico-patrióticos, específicamente a los festejos del centenario de la independencia.

Palabras clave: ejercicio del poder; nacionalismo; rituales cívico-patrióticos; invención de la tradición; estatuomanía; panoptismo; Hermosillo; porfiriato.

Abstract: this article offers an interpretation of the exercise of power by the State and the ruling elite during the Porfiriato, 
through an analysis of Hermosillo's urban space. The analysis highlights the symbolic functions of the monuments, buildings and other urban facilities constructed in the city during this period. Three types of phenomena are studied in order to validate the assumption that Hermosillo's street nomenclature is a cohesive and identity-constructing element which seeks to generate a patriotic and nationalist consciousness: first, Michel Foucault's panopticism perspective; second, "statue mania," an obsession of the era with creating monuments in order to promote liberal values; and third, in accordance with Eric Hobsbawm's proposal, the invention of tradition, applied to civic and patriotic rituals, particularly the celebrations of Mexico's Centenary of Independence.

Key words: exercise of power; nationalism; civic and patriotic rituals; invention of tradition; statue mania; panopticism; Hermosillo; Porfiriato.

Introducción

En el horizonte del siglo xxI no cuesta trabajo concebir a México, y a su población, como una nación en las postrimerías del XIX e inicio del Xx. Es decir, pareciese que la nación y el sentimiento de comunidad imaginada ${ }^{1}$ hubiesen existido y estado presentes desde la propia consumación de la independencia. Sin embargo, esto es dudoso, al menos en términos de la existencia de un proyecto de unificación mediático que permitiera la consolidación de un territorio y comunidad, con sus respectivos lazos afines y estrategias para salvaguardar intereses. Duda que es posible refutar, si se considera que desde la

1 Benedict Anderson (1993), de quien se retoma el concepto, considera a la nación como una comunidad imaginada, es decir, un grupo social o, como lo señala el concepto en un sentido antropológico, una "comunidad” que se piensa de manera colectiva en términos políticos, culturales y sociales ubicados en cierta territorialidad, donde existe compañerismo. La nación es una entidad ilusoria, una construcción social en la que los individuos se imaginan como comunidad independientemente de sus diferencias y la pluralidad de significados que le otorgan a su entorno, logrando así un compañerismo. 
emancipación hasta finales del siglo XIX coexistieron fases de inestabilidad política, deficiencia de paz social e incluso falta de compromiso ideológico: republicanos contra monárquicos, centralistas contra federalistas, conservadores contra liberales y después el Estado contra la Iglesia. ${ }^{2}$

Aunado a lo anterior, los contornos entre los integrantes de cualquier bando político estaban determinados por sus intereses personales y clientelares. ${ }^{3} \mathrm{~A}$ lo que hay que sumar el referente regional de caudillismo y de los cacicazgos locales, los conflictos con grupos étnicos y las pugnas por el poder. El panorama era complicado y poco propicio para la concreción de una nación. Pero a partir de la segunda mitad del siglo XIX, a merced de distintos acontecimientos, se propició una conciencia del territorio y de reconocimiento como mexicano. ${ }^{4}$ No obstante, fue hasta el ascenso de Porfirio Díaz a la Presidencia cuando se generó una estabilidad política, paz social y las condiciones que permitieron que se impulsara un proyecto de Estado-nación.

Durante este periodo se generaron algunos cambios en la esfera administrativa, para la concreción de tal empresa, sobre todo la inserción de factores de distinta índole como el nacionalismo, ${ }^{5}$ con el

2 La segunda mitad del siglo XIX se muestra con una difícil marcha de la doctrina liberal, consecuencia de una sociedad tradicional (Guerra 2012,193), así como invadida de luchas ininterrumpidas de las que se derivan la pérdida de gran parte del territorio nacional en 1848 -y la falta de reacción del pueblo- a causa de la guerra contra Estados Unidos, lo cual dilucidaba la inexistencia de unión pero, sobre todo, de una nación como tal (Vázquez 1998, 68).

3 Clientelismo hace referencia a prácticas entre sujetos que conllevan privilegios, derechos y deberes recíprocos a fin de hacerlos valer, los cuales suelen ser establecidos o se dan de manera implícita. Para que dichas prácticas se lleven a cabo se requiere un sistema de alianzas o vínculos entre facciones, grupos o sujetos con una serie de relaciones establecidas entre sí (Guerra 2012, 151-153).

4 Uno de los primeros indicios (de algunas facciones) sobre una conciencia e intención por generar una idea de nación proviene de la promulgación del Plan de Ayutla y las modificaciones realizadas por Comonfort, en las que se planteaban el desconocimiento del centralismo y la constitución de un gobierno republicano (De la Torre 1986, 263-266). No obstante, se reavivaron las tensiones tras una lucha de facciones entre liberales, conservadores y radicales descuidando así un plan de concreción para el fortalecimiento o reinvención del Estado. Una intervención francesa, la proclamación de un segundo imperio, y después la expulsión francesa generó la conciencia de un territorio propio y los indicios de una idea de nación, sin embargo, continuó la inestabilidad política y lucha de facciones hasta la entrada de Díaz al poder.

5 El nacionalismo lo situó, al igual que la obra de Anderson, en el siglo XIX, quien hace referencia a la formación de las naciones y al surgimiento de la ideología y movimientos na- 
que se trataba de ejercer un sentimiento colectivo buscando la identidad y la cohesión de la población. En función de ello se evidenció que se entremezclaran los aspectos étnico e histórico. De ellos se desprenden otros de los cuales echaban mano para su difusión, con tal de que entre los individuos se asimilara una conciencia de nación. Lo étnico generaba una vinculación entre los individuos, que en una comunidad se traduciría en términos de Estado-nación y lo histórico. El objetivo de la reconstrucción histórica y la recopilación de símbolos del pasado era crear una identidad propia, pero sobre todo de un proyecto de nación. ${ }^{6}$ Prueba de ello es la existencia de una historia que insistía en representar los procesos colmados de coherencia, es decir, de una forma encadenada o adaptada desde su comienzo hasta su presente, ${ }^{7}$ de tal forma que se presentaba como seria, científica y única. Además de que instruía al mexicano y exaltaba su pueblo con el fin de identificarlo, inspirarlo, pero sobre todo que legitimaba y justificaba el ascenso de Díaz y su régimen al poder (Zamora 2003, 172).

cionalistas, y se le asocia con una doctrina o teoría política, con origen en los movimientos conocidos como ilustración y revolución francesa, de las cuales se desprende a su vez el pensamiento universalista (de la razón). En México habría de suscitarse entremezclado con la doctrina liberal durante el periodo porfirista, que pasó por un largo proceso que se concretó hasta finales de este régimen: Anderson (1993); Muguerza (2000) y Brading (1980).

6 Porfirio Díaz reconocía la utilidad de la historia como un elemento unificador de la nación, ejemplo de ello es su planteamiento en la entrevista que James Creelman le hizo en 1908. Donde Díaz señala: “[...] Quiero ver la educación difundida por todo el país, llevada por el gobierno nacional. Espero verlo antes de morir. Es importante para los ciudadanos de una república el recibir todos la misma instrucción, de modo que sus ideales y sus métodos puedan armonizar y se intensifique así la unidad nacional. Cuando los hombres leen las mismas cosas y piensan lo mismo, están más dispuestos a actuar de común acuerdo” (Luján 1963, 51).

7 Una especie de genealogía en términos de Foucault en la que se da la creación de "falsos orígenes" u "orígenes ilusorios", para el caso de los procesos de formación de la nación, pero sobre todo para la justificación del ascenso y permanencia de un régimen como lo fue el porfiriato (Foucault 2000). Del mismo modo, ya habían existido proyectos para la creación de una historia con versiones que legitimaran la posición de los nuevos grupos gobernantes, desde La historia antigua de México, de Francisco Xavier Clavijero (para exaltar a los criollos), hasta mediados del XIX con Cuadro histórico de la revolución mexicana, de Carlos María de Bustamante (para legitimar a los liberales del contexto). Esto trascendió hasta los escritos de liberales de segunda generación como Ignacio Ramírez e Ignacio Comonfort, quienes crearon un panteón de héroes y se concebían como descendientes de la independencia (Brading 1980, 141). 
Una historia que rescataba los orígenes del pueblo mestizo, que evocaba las hazañas heroicas del pasado y que, en suma, daban como resultado el presente en el que se encontraba el nuevo mexicano. El producto de tal proyecto fue México a través de los siglos de Riva Palacio. ${ }^{8}$ Con este tipo de historia se conciliaban todos los pasados para crear un presente, con miras al futuro en el que estaba de por medio la concreción de una nación.

Asociados al nacionalismo, la construcción de una nación y los aspectos que le preceden (étnico e histórico), surgen varios fenómenos que se entremezclan con ello. Por un lado la creación tanto artística como cultural, sobre todo la que destacara en el espacio urbano, ${ }^{9}$ mediante obras escultóricas y arquitectónicas. Por otro, surge un afán monumentalista por parte del Estado en el que se plasmara, a través de las obras artísticas, el interés por crear una cultura nacionalista con la intención de dar una identidad nacional (Shávelzon 1988, 21).

\section{La ciudad y su efecto simbólico}

De acuerdo con Brenes $(2004,112)$, es posible argumentar que durante el régimen liberal de Díaz, con el fin de inculcar una lealtad

$8 \quad$ Esta obra consta de cinco volúmenes, en ella se exalta la historia de bronce y se justifica el ascenso del pueblo mexicano, al mismo tiempo es una sola versión de hechos del pasado con miras a la legitimación del ascenso del régimen de Díaz. El acierto más grande de esta obra fue que reunió pasados hasta entonces contradictorios como la antigüedad prehispánica y la conquista, la Colonia y la independencia; el centralismo y el federalismo, de una manera maniquea y positivista (Florescano 2001b, 63; Riva Palacio 1968).

9 El espacio urbano se concibe como la entidad -cambiante-, “orgánica” (Hardoy 1964), en el sentido de que está en constante desarrollo o determinado por una variedad de factores. Asimismo, el espacio urbano es inherente al de ciudad. La palabra "urbano" refiere propiamente a un adjetivo que señala "perteneciente [o relativo] a la ciudad” (Real Academia Española, RAE $1869,775,1)$ por lo tanto, es el espacio ocupado por una ciudad. Mientras que el concepto de ciudad refiere a "una población comúnmente grande que en lo antiguo gozaba de mayores privilegios que una villa” (RAE 1899, 229,1), también se le conoce como el conjunto de calles, casas, edificios que componen propiamente ésta (RAE 1869, 177), en relación con el planteamiento anterior, a este tipo de construcciones se les denomina equipamientos colectivos, un término referente al conjunto de instalaciones físicas y privadas como son las edificaciones y plazas cuyo fin era cumplir las necesidades básicas de una ciudad y el desarrollo de su población (Georg 2004, 51-77). 
afectiva hacia la nación y de forjar patria, se (re)crearon y (re)elaboraron representaciones colectivas, tradiciones e imaginarios en los que diversos grupos sociales podían encontrar -simultáneamenteuna identidad, tanto colectiva como secular. Este nacionalismo se manifestó y se hizo patente en espacios públicos en las ciudades del país. El caso más emblemático es la Ciudad de México, donde confluyen los poderes del Estado, así como la extensión poblacional, y el mayor desarrollo urbano y arquitectónico. Hay obras que rescatan el aspecto monumentalístico, arquitectónico y su énfasis en el nacionalismo, como las de Verónica Zárate Toscano (2010 y 2001), Antonio Bonet Correa (1980), Carlos Martínez Assad (2005), Ramón Vargas Salguero (1989), Federico Fernández (2000), Barbara Tenenbaum (1994), Mauricio Tenorio Trillo (1998), Celia Berkstein (2004), Annick Lempérière (1995), Arnaldo Gutiérrez Moya (2007) y Enrique X. de Anda (1995). Algunas se centran en la descripción de los aspectos estéticos, en tanto que otras marcan el relieve en que las obras públicas y monumentos fueron medios para la legitimación y reafirmación del régimen de Díaz, cada una desde enfoques y alcances historiográficos distintos.

Desde la propuesta de Françoise Choay, en el urbanismo culturalista ${ }^{10}$ los equipamientos colectivos constituyen el soporte de otras tantas significaciones imaginarias o simbólicas. Desde la óptica del consumo, la población, a través de los equipamientos colectivos, se apropia de lo simbólico y recrea imaginarios y representaciones ${ }^{11}$

10 De acuerdo con Choay (1965), Mumford y Barthes y Lefebvre (1976) la ciudad y sus equipamientos colectivos son una obra cultural antes que funcional, un campo de significaciones y representaciones simbólicas, un libro que se lee. Cada piedra es un signo, cada forma es un símbolo, y el hombre cultural implicado en esta concepción vive en una ciudad simbólica, animada por representaciones (Fourquet y Murard 1978, 23).

11 Los imaginarios están relacionados con el nacionalismo, mientras que las representaciones están apegadas a los rituales cívicos-patrióticos y al afán monumentalístico del porfiriato. En el presente se utiliza el imaginario en términos de Wunenburger, quien se refiere a ellos como las producciones mentales o materializadas en obras, basadas en imágenes visuales (pinturas, dibujos, fotografías) o en formas de habla (metáforas, símbolos, narraciones), que forman conjuntos coherentes y dinámicos en los que destaca una función simbólica expresada en la conjunción de sentidos propios y figurados $(2003,10)$. Estas producciones pueden mantenerse como simples procesos psicológicos, aunque cuando son proyectados, materializados y compartidos se trasforman en sistemas simbólicos, en obras basadas en imágenes visuales o en forma de habla las cuales adquieren un carácter social (Castoriadis 2004, 23). Para los fines del presente estudio se destacan dos aspectos que producen los imaginarios dentro de una sociedad determinada: coherencia a la realidad y cohesión social; coherencia 
(Fourquet y Murard 1978, 25). Aunado a ello se encuentran las formas en las que se consumen los símbolos que emergen de los equipamientos como el panoptismo, retomado de Michel Foucault, los elementos mediáticos y los rituales cívico-patrióticos, categorías utilizadas en este trabajo.

El objetivo del presente artículo es evidenciar un ejercicio del poder, ${ }^{12}$ a través del espacio urbano y del cumplimiento de funciones simbólicas de la ciudad, como las que cumplieron los equipamientos de ésta durante la época finisecular. Para explicarlo se retoman tres tipos de fenómenos: a) la nomenclatura de las calles como elemento cohesionador y generador de una conciencia patriótica y nacionalista; b) la estatuomanía, obsesión de la época por generar monumentos y c) los rituales cívico-patrióticos, como elementos cohesionadores de una misma índole.

\section{De la localización y el olvido a la memoria: la toponimia y nomenclatura de las calles}

Existen objetos creados especialmente para ayudarles a las personas a recordar. Esto lo consiguen gracias a su forma y localización, así

en el sentido de que los propios sujetos sociales crean una realidad imaginada, la cual se haya configurada por imaginarios sociales que le dan sentido a una realidad consensuada, en función de que se asimilen a partir de una temporalidad y espacialidad dada (Baczko 1991, 56) Por otro lado, las representaciones sociales son la sustitución de la realidad o bien de algún significado de la realidad. En tanto que los significados están construidos e implementados en el conjunto de vida para actuar y dar sentido. Asimismo, la representación social está orientada a comprender el significado que la gente pone a su existencia cotidiana, para dar sentido a su misma vida (Rodríguez 2003). En otras palabras, las representaciones sociales son "formas de pensamiento de sentido común, socialmente elaboradas y compartidas, que les permiten a los individuos interpretar y entender su realidad y orientar y justificar los comportamientos de los grupos" (León 2002, 369).

12 La capacidad de actuar, de producir efectos sobre algo o alguien más, como un fenómeno en constante movimiento en el cual los sujetos sociales lo ejercen o producen, a través de distintos factores (Bobbio 1982, 1217), en este caso se sugieren elementos que fungieron como dispositivos mediáticos. Se retoma a Weber (1984), quien define a dicha "capacidad de actuar" como una relación asimétrica, es decir, dada por un control diferencial de los recursos de dominación, entre ellos medios (cualidades y posesiones) para imponer la propia voluntad a otro u otros. Por lo tanto, se considera el ejercicio del poder como la capacidad de generar, impartir, controlar, persuadir y convencer a los individuos o sujetos sociales, ya sea por medios, tácticas, estrategias o dispositivos generados por el sujeto o ente dominante. 
como el texto que suelen llevar. Algunos son rasgos relativamente constantes del medio ambiente, como una lápida o una inscripción en honor de una autoridad local. Otros son marcadores transitorios de un hecho para recordar (una bandera en la cima de una montaña, un listón negro en referencia fúnebre) o de una acción por emprenderse (un nudo en el pañuelo). En ambos casos -transitorio o permanente-, la gente crea objetos o instala artefactos para que algo sea recordado o conmemorado en el futuro. Por lo tanto, el mundo de los objetos como cultura material representa el registro tangible de los logros humanos, tanto sociales como individuales (Radley 1992, 65).

En cuanto al argumento de Radley, las nomenclaturas de las ciudades han fungido como elementos destinados a la ordenación de sus calles y lugares, desde una perspectiva funcional, ya sea para orientarse o no olvidarse de ellos. Pero también han fungido en "el mundo de la cultura material" -y desde la lógica del consumo y de los elementos mediáticos-, como símbolos y representaciones para evocar acontecimientos históricos, próceres y héroes patrios, así como ciertas particularidades propias del contexto en el que se emitió dicha regulación. Por tanto, la nomenclatura de las calles, plazas, ciudades y demás fungen en ocasiones como elementos creados a fin de que influyan en la generación y pervivencia de un imaginario colectivo.

La creación de la nomenclatura de Hermosillo se remonta a finales del siglo xIX; antes no se contaba con una oficial y específica, por lo que en ocasiones la población le adjudicaba uno o varios nombres a las calles. Un ejemplo es la actual calle Aquiles Serdán, la cual tomó el nombre de calle Real, a partir de la fundación del Pitic (hoy Hermosillo), y lo conservó hasta 1825. Partía de la alameda (hoy parque Madero) hacia el poniente, hasta la iglesia primera (San Antonio), desde 1826 hasta 1890 fue conocida como la calle de Los Molinos y también de La Alameda, mientras que la voz popular la llamó de Los Naranjos y hasta calle de María Amparo, durante el porfiriato llevó el nombre de Don Luis, en honor a Luis E. Torres ${ }^{13}$ (Galaz 1996,

13 Luis Emeterio Torres fue un político perteneciente al triunvirato porfirista, garante del progreso del régimen y uno de los combatientes acérrimos en la campaña en contra del grupo yaqui (García 1905-1907). 
440; Escobosa 1995, 130). Cuando no se le adjudicaba nombre a las calles, era usual que la población usara elementos asociados con ellas, por ejemplo el referente agrario, para fines de orientación era recurrente señalar la calle de la acequia mayor, la que da al río, el callejón, la del puente colorado, la que da a la huerta de tal, entre otras (Galaz 1996, 440).

\section{Figura 1}

Nueva nomenclatura de las calles según la procedencia de sus nombres

\begin{tabular}{|c|c|c|c|c|c|c|}
\hline $\begin{array}{c}\text { Estados } \\
\text { y ciudades } \\
\text { del país }\end{array}$ & $\begin{array}{c}\text { Regiones } \\
\text { del } \\
\text { estado }\end{array}$ & $\begin{array}{c}\text { Héroes de la } \\
\text { independencia }\end{array}$ & $\begin{array}{l}\text { Héroes de } \\
\text { la reforma }\end{array}$ & $\begin{array}{l}\text { Relativos } \\
\text { al grupo } \\
\text { porfirista }\end{array}$ & $\begin{array}{c}\text { Nombres } \\
\text { tradicionales }\end{array}$ & $\begin{array}{c}\text { Héroes: } \\
\text { invasión } \\
\text { EE UU y } \\
\text { otros } \\
\text { personajes }\end{array}$ \\
\hline Tehuantepec & Arizpe & Victoria & Rosales & Don Luis & Del Carmen & Urrea \\
\hline Guanajuato & Cucurpe & Narbona & $\begin{array}{c}\text { M. } \\
\text { González }\end{array}$ & $\begin{array}{l}\text { Porfirio } \\
\text { Díaz }\end{array}$ & Del Cerro & Arista \\
\hline Orizaba & Oposura & Ramírez & B. Juárez & Reyes & Del Rastro & Comonfort \\
\hline Querétaro & Bavispe & Iturbide & G. Morales & Carbó & $\begin{array}{c}\text { De la } \\
\text { Moneda }\end{array}$ & Ocampo \\
\hline Chiapas & & Rosales & Yáñez & & \begin{tabular}{c|} 
Del \\
Ferrocarril
\end{tabular} & Astiazarán \\
\hline Tabasco & & Matamoros & Pacheco & & Del Río & \\
\hline Celaya & & Guerrero & Escobedo & & & \\
\hline Tampico & & Mina & Lerdo & & & \\
\hline Chihuahua & & Álvarez & & & & \\
\hline Campeche & & Hidalgo & & & & \\
\hline Monterrey & & Morelos & & & & \\
\hline Morelia & & Allende & & & & \\
\hline Jalapa & & Bravo & & & & \\
\hline Yucatán & & Galeana & & & & \\
\hline
\end{tabular}

Fuente: a partir del plano topográfico de 1900 de Hermosillo (véase figura 3 del anexo), donde aparecen los nombres otorgados a las calles de la ciudad. 
En un plano hablado de Hermosillo, que data de 1835 (véase figura 1 del anexo), sólo algunas calles poseen nombre, como la Del Cupido, que va a la acequia, el callejón que conduce a los pinos, la Guamuchilares y la que iba al río, las demás sólo aparecen como “calle”. Por ende, la población recurría a las improvisaciones mencionadas, para solventar la carencia de nombres oficiales. El siglo XIX trascurrió de manera pasiva, en cuanto a la adecuación de algún servicio de nomenclaturas, cuando menos la inexistencia de fuentes así lo indica. No obstante, a finales de siglo la prensa exhortaba al ayuntamiento para que trabajara en un proyecto de nomenclatura, por ejemplo en 1876 el periódico La Regeneración lo hizo evidente, a razón de la desorientación de los visitantes (Carrasco 1876).

En 1883, durante la gestión del gobernador porfirista Luis E. Torres, se implementaron ciertas medidas a fin de reorganizar la ciudad y darle mejor imagen, por ejemplo se plantaron árboles o se penalizaba a los vecinos por tirar la basura y excrementos en las acequias. No obstante, la propuesta más trascendente fue la de dotar a las calles de una nomenclatura oficial, proyecto que estuvo a cargo del ingeniero Francisco Dable (Galaz 1996, 440; Karp 1992). Sin embargo, sólo se menciona el documento sin haber evidencia de éste, por lo que la segunda fuente más precisa son los planos topográficos de 1895 y 1900 (véase figuras 2 y 3 del anexo), donde ya aparece la nueva nomenclatura de las calles de Hermosillo con nombres muy particulares.

En dicha representación, de sur a norte, figuraban algunos nombres de ciudades y estados de la república mexicana, de oriente a poniente se incluían los de héroes de la independencia y la reforma, a las calles de las inmediaciones del cerro de la Campana (referente urbanístico y eje unificador de la ciudad) se le adjudicaron nombres de regiones sonorenses. Asimismo, se conservan algunos tradicionales que hacían referencia a algún elemento, por ejemplo Del Carmen, Del Cerro, De la Moneda, Del Río, entre otros y también aparecen nombres de personajes del grupo porfirista, como Don Luis (en referencia a Luis E. Torres), Porfirio Díaz y Reyes (en relación con Bernardo Reyes).

En teoría, la nueva nomenclatura desplazó a los nombres anteriores, pero también se adquirió una racionalización, ordenamiento y control del espacio urbano y poblacional. De igual forma, con este tipo de prácticas se cumplían otros objetivos, bajo el supuesto de que, 
al dotar a las calles con nombres de personajes importantes de la historia nacional y regional, se exaltaba un patriotismo por medio del cual se intentaba construir un imaginario de la nación. Este supuesto va en función de que, en la percepción de la población, se haría patente la idea de una nación a partir de su representación en la nomenclatura, ahora aparecía Sonora con los demás estados de la república. ${ }^{14}$ También pervivían los nombres de héroes de la independencia y de la reforma, así como los porfiristas ilustres, por ejemplo Porfirio Díaz y Luis Emeterio Torres, quienes ahora se hacían dignos de tener en la localidad una calle con su nombre.

Bajo el supuesto del panóptico, es posible observar entonces una acción disciplinaria a través del espacio urbano, en el sentido de educar a la sociedad, puesto que a partir de la creación de una nueva nomenclatura con elementos patrióticos y de nacionalismo era posible persuadirla e inculcarle el imaginario de la época. ${ }^{15}$ El imaginario de

14 Es posible identificar este fenómeno en otros lugares del país, el más típico es la Ciudad de México, donde se promovió la exaltación de héroes regionales con la colocación de estatuas en el Paseo de la Reforma (Sosa 1996; Martínez Assad 2005).

15 Foucault se interesa por el fenómeno del poder en función de darle mayor importancia a la manera en que éste se presenta, es decir sus formas y resistencias. En tanto que al hablar de poder y espacio surge una propuesta para el análisis del poder tomando en cuenta el espacio como una entidad que sirve de dispositivo o medio para el ejercicio de éste. Dicha propuesta es el panóptico, un medio para alcanzar fines disciplinarios, del que se deriva el término panoptismo. El cual funge como un concepto-categoría creado y utilizado por Foucault, por un lado expresa una forma de organización espacial y jerárquica que data del siglo XVIII y con gran presencia en el XIX, para situaciones de lo que Foucault llama “de crisis". El referente mejor materializado del panopticismo es el panóptico, un diseño arquitectónico de finales del siglo xvıII, creado por Jeremy Bentham, y diseñado para el encierro penitenciario, así como su uso en instituciones con espacios cerrados. Por otro lado se encuentra el panoptismo en términos de categoría de análisis del poder. Un principio general que plantea Foucault sobre las nuevas formas de anatomía política es que sus objetos y finalidades no son las relaciones de soberanía, sino las de disciplina (Foucault 1991, 208). El panoptismo no es, en absoluto, reductible conceptualmente a la operación arquitectónica, particular y específica, que realiza el panóptico de Bentham. El término panoptismo captura no tanto el papel que desempeñan arquitecturas y proyectos institucionales concretos, como la naturaleza y devenir de un amplio y complejo espectro de técnicas disciplinarias, a través de las cuales los sujetos humanos son trasformados en “cuerpos dóciles”. Más bien, ve en la arquitectura un medio de instrumentalización del poder a partir del espacio como terreno concreto para el ejercicio de tal función (Tirado 2002, 23). Por lo tanto, el espacio cobra importancia y se convierte en un medio para el alcance de un fin, la persuasión y control de los individuos. Por ello se puede entender que en el trabajo del espacio es donde radica la producción de individuos socialmente útiles y competentes. El individuo se caracteriza por ser un animal disciplinado (Tirado 2002, 26). En función de lo anterior, algunas obras de la época porfirista se clasifican como monumentos, calles y plazas como mecanismos independientes que ejercen los efectos del panoptismo. 
nación recreado en sus calles pero, sobre todo, tratando de legitimar el régimen de Díaz en función de que también nombres alusivos a éste se incluían en la nueva nomenclatura.

Otros elementos de transición fueron el paso de un espacio tradicional a uno moderno, y a una resignificación ideológica sustentada en el tránsito de la cultura clerical y tradicional a una "ciudad moderna”, cívica y laica. Este supuesto va en función de que se despojó a ciertas calles de sus antiguos nombres como de La Ermita, de Jesús Nazareno, Del Retiro, de La Amargura, de La Soledad, Del Piojo, para sustituirlos por Tabasco, Manuel González, Yáñez, Carbó, Iturbide, Porfirio Díaz y Monterrey, entre otras.

Las plazas, los parques y los jardines, que se incorporaban a esta parafernalia del poder con sus nombres, también promovían el ideario patriótico. Sitios como la plaza Zaragoza, los parques Pesqueira y Ramón Corral y, con el paso de algunos años, el jardín Juárez y la plazuela Hidalgo. Todos ellos evocaban acontecimientos y forjaban reconocimientos a las insignes fechas y próceres patrios; como la independencia, el Cinco de Mayo, la expulsión francesa y la reforma. Mientras que el parque Ramón Corral reconocía a un porfirista de la región. ${ }^{16}$

En la nueva nomenclatura, además de percibir el fomento del ideario nacionalista, también se advierte el elemento simbólico del culto a los héroes. Por lo que el segundo elemento característico de la nueva nomenclatura fue la promulgación e inculcación de nombres de insignes patrios que, según la historia "oficial" -construida por el grupo porfirista-, habían servido a la patria. Así se apostaba por la generación de un recordatorio permanente entre la sociedad de las virtudes cívicas, patrióticas y liberales de dichos héroes y del actual gobierno, que los representaba y se concebía acreedor de su herencia.

No obstante, es posible inferir una dicotomía en dicho ejercicio del poder, pues años después de la implementación de la nomenclatura oficial, a principios del siglo xx, es posible observar en los documentos oficiales así como en el ideario público una especie de

16 La población le había adjudicado este nombre, tras una iniciativa de un ciudadano, asimismo el Congreso aprobó la propuesta (Galaz 1996, 329; Archivo General del Estado de Sonora, AGES: fondo Ejecutivo, tomo 1684). 
resistencia o tradicionalismo, en el sentido de que se seguían conservando o usando los viejos nombres de las calles y las plazas. ${ }^{17}$ Lo cual denota una especie de resistencia por parte de algunos sectores de la población.

\section{Estatuomanía porfirista}

La propagación del nacionalismo se hizo patente por medio de otros dispositivos mediáticos como la estatuomanía, ${ }^{18}$ un fenómeno nacional ocurrido hacia 1888, mediante el cual se buscó reafirmar la identidad y unidad de los mexicanos, y las intenciones del régimen eran fomentar y cultivar la erección de estatuas. ${ }^{19}$ En Hermosillo es posible observar este fenómeno a partir de la iniciativa de Francisco Sosa y la aprobación de Díaz de erigir estatuas de héroes ilustres en el Paseo de la Reforma. ${ }^{20}$ En 1889, los porfiristas en Sonora, bajo la administración de Ramón Corral y Luis Emeterio Torres, se encargaron de darle seguimiento a tal convocatoria. Eligieron como héroes a los caudillos Ignacio Pesqueira y Jesús García Morales, y colocaron sus estatuas en el Palacio de Gobierno, un espacio semipúblico (Escobosa 1995, 75-76). Ambos participaron en la guerra de reforma, en la sostenida contra la intervención extranjera y el segundo imperio, y también eran personajes políticos de Sonora. El primero murió en 1886 y el segundo en 1883, época en la que ya estaba instaurado el grupo porfirista, por lo que estaba muy vigente el sentido de conmemorar

17 Por ejemplo, en los oficios del ayuntamiento referentes a la pavimentación de las calles de Hermosillo se siguen utilizando nombres como de La Amargura, Del Piojo, Del Datilito, sin implementar de forma oficial los agregados a finales de siglo (AGES: fondo Ejecutivo, tomo 1583, expediente 3, varias fojas, año de 1900).

18 El término estatuomanía, retomado de Maurice Agulhon, se usa para referirse al proceso de monumentalismo excesivo y de decorado urbano que se dio durante el porfiriato, a fin de incluir estatuas de héroes de sucesos históricos en todo el país. Agulhon utiliza éste término para referirse a la etapa escultórica de la época finisecular en Europa y América, caracterizada por la consolidación de la burguesía, el triunfo de las repúblicas liberales y la segunda revolución industrial (1994,120-161; Zarate 2010, 93; y Lempérière 1995, 321).

19 En lo que respecta a estatuas de héroes, se rescata la existencia de la de Hidalgo, en Toluca; la de Morelos, que hizo erigir Maximiliano; la de Hidalgo, en San Luis Potosí; los cenotafios en memoria de Hidalgo, en Chihuahua; de Morelos en Ecatepec, y la de Cuauhtémoc, en el Paseo de la Reforma (Monsiváis 1992, 105-128)

20 AGES: tomo 679, fondo Prefecturas: Ramo de Fomento, expediente s/núm, foja s/núm. Véase invitación o comunicado al gobierno del estado de Francisco Sosa, año de 1887. 
su vida y obra. ${ }^{21}$ También se edificó una estatua en honor a Miguel Hidalgo, en la plaza Centenario.

Para la creación de las esculturas de los dos insignes sonorenses se recurrió al escultor Henry Alciati, de origen franco-italiano y con residencia en México. ${ }^{22}$ El contrato incluía la instauración de las estatuas hechas en bronce para el Paseo de la Reforma, después la creación e instalación de réplicas en yeso para el Palacio de Gobierno. ${ }^{23}$ Contrario al material propuesto inicialmente para el Paseo de la Reforma, las réplicas en yeso denotaban menos resistencia aunque mayor facilidad de uso, según el contrato con Alciati, la confección y reproducción en yeso era sólo una forma de embellecer el palacio. ${ }^{24}$

La estatua de Hidalgo se hizo en el marco de los festejos del centenario, en 1910, para lo que se formó el Comité de Suscripción Popular Pro-monumento del Padre Miguel Hidalgo. Sin embargo, después el encargo lo asumiría la comisión del centenario. ${ }^{25}$ Este hecho promovió la creación de otras y también de monumentos en el país. La estatua de Hidalgo fue consignada, en un proyecto desde 1908, al arquitecto italiano Aquiles Baldassi. ${ }^{26}$

En el marco de los festejos del centenario se construyó el jardín Hidalgo, ubicado en la calzada Centenario, inaugurada el 15 de septiembre de 1910. Al día siguiente, en un acto simbólico, fue colocada la primera piedra de lo que sería el monumento ya encargado, cuya base sería de mármol de Carrara, Italia, y la estatua de bronce. ${ }^{27}$

Cabe destacar que hubo otros proyectos monumentalísticos regionales, sin embargo se quedaron como iniciativa, y en algunos casos se emprendieron y fueron abandonados. Entre ellos, un monumento

Alciati figuraba como un artista plástico importante, era maestro de la Escuela Nacional de Bellas Artes. En 1910 realizó la escultura del Ángel de la Independencia (Pérez 2010, 36-43).

23 s/núm, foja s/núm.

24 AGEs: tomo 679, fondo Prefecturas, Ramo de Fomento, expediente s/núm, foja s/núm.

25 AGEs: fondo Ejecutivo, tomo 2583, expediente s/núm. Noticia de las mejoras materiales inauguradas por motivo del primer centenario de independencia. 8 de octubre de 1910.

26 Archivo Histórico del Ayuntamiento de Hermosillo, AHAH: caja 35, tomo 5. Proyecto de contrato para la erección de un monumento a Hidalgo, 1908.

27 Con un costo de $\$ 12000$ junto con la instalación (AGES: fondo Ejecutivo, tomo 2583, expediente s/núm. Noticia de las mejoras materiales inauguradas por motivo del primer centenario de independencia. 8 de octubre de 1910). 
a Antonio Rosales y Antonio Molina, en Álamos, ${ }^{28}$ y otro en honor a Juárez, que se pretendía erigir en Bacoachi. ${ }^{29}$ Esto se debió a la falta de capital, financiamiento del estado y apoyos federales y de organización, es decir, de clubes, juntas patrióticas u organismos no gubernamentales que emprendieran tales empresas, aunque el factor más fuerte fue la falta de escultores hacia finales de siglo y de algún taller de escultura o grabado en la región. ${ }^{30}$ Sin embargo, este tipo de situaciones se solventaban recurriendo a arquitectos y artistas de fuera de Sonora. 31

El financiamiento de este tipo de obras era sufragado de lo recaudado por colectas entre las organizaciones como la Junta Patriótica o la Comisión del Centenario, asimismo, se contaba con el apoyo de otros distritos y, por ende, de sus municipios. ${ }^{32}$ En otras partes del país se recurría a los comerciantes e industriales, así como a comités y gobiernos de otros estados. ${ }^{33}$

\section{Algunas consideraciones sobre la estatuomanía}

\section{Carlos Martínez Assad señala que "un monumento o una estatua, nos} habla mucho más del estilo artístico en el que fue creado. Nos habla

AGEs: fondo Ejecutivo, tomo 1734. Comunicado del alcalde A. Salido a Rafael Izábal. Agosto de 1902.

29 En vista de no haber adquirido la cantidad requerida para dicho monumento, se acordó levantar un cerco para la plaza del lugar (AGES: fondo Ejecutivo, tomo 2243. 1907. Informe del Ayuntamiento sobre las mejoras materiales correspondientes a 1905 y 1906).

30 Este tipo de problemáticas eran precisadas cuando la comisión mexicana para la Exposición Universal de París, de 1900, solicitaba fotografías, bosquejos o documentos sobre los posibles monumentos en Sonora (AGES: fondo Ejecutivo, tomo 1714, expediente s/núm, foja s/núm. con fecha del 29 de noviembre de 1898; tomo 2552, Inventario de la Comisión Nacional del Centenario de la Independencia. 6 de octubre de 1908).

31 Para el primer caso se encuentra el arquitecto Aquiles Baldassi, a quien le fueron encomendados algunos trabajos de ornato en la sala de recepciones del Palacio de Gobierno, principalmente arte estucado, así como la creación de varias piezas escultóricas de alto relieve para adornos del Palacio, y la ya mencionada estatua de Miguel Hidalgo (AGES: fondo Ejecutivo, expediente I. 3 de enero de 1910; АHAH: caja 35, tomo 5. Proyecto de contrato para la erección de un monumento a Hidalgo, 1908). En el segundo caso se encuentra el escultor italiano Henry Alciati, quien residía en la Ciudad de México y se encargó de las estatuas de Pesqueira y Morales desde su taller (AGES: tomo 679, fondo Prefecturas, Ramo de Fomento, expediente s/núm, foja s/núm). AGES: fondo Ejecutivo, tomo 2585, expediente s/núm, foja s/núm.

33 Véase al respecto los monumentos para la Constitución de 1857 en 1901 (AGEs: fondo Ejecutivo, tomo 1660, expediente 4), a Morelos en Morelia en 1903 (AGES: fondo Ejecutivo, 
sobre una identidad en formación, un contexto político en el cuál se trataba de exaltar la cuestión patriótica, asimismo, revive la cuestión ideológica de una sociedad" (2005, 34). A partir del supuesto anterior es posible apreciar distintas intenciones del régimen, al fomentar la edificación de monumentos y estatuas. Por ejemplo, que le dieran a la ciudad donde se había erigido el mérito de civilidad y la distinción de histórica, ya que resguardaban símbolos patrióticos del pasado, así la destacaría frente al extranjero, bajo la insignia del espíritu del progreso irradiado, y el elemento de la memoria. Aunque el más fuerte, de acuerdo con Martínez $(2005,36)$, era la formación de una identidad, la cual se encuentra inherente al elemento de la memoria.

El elemento de la memoria era el medio para gestar la identidad nacional. Una forma de hacerlo era por medio de la historia, pero también de las estatuas, en el sentido de que éstas fungían como elementos educativos, es decir, el grupo porfirista "sacó la historia" a las calles a fin de fomentar las virtudes cívicas de los héroes en los ciudadanos (Zamora Müller 2003, 179). ${ }^{34}$ De esta forma, el Estado era la institución que delegaba con la memoria y el olvido y, en función de ello, el uso que se le daba al pasado en su horizonte temporal recreaba un sentido de conciencia histórica, fomentada por los monumentos y obras emblemáticas. ${ }^{35}$

Un ejemplo es el uso implícito de las estatuas del Palacio de Gobierno, bajo el supuesto de que funcionó como un medio de reivindicación con el pasado -con el que los gobernantes hacen las paces-. Curiosamente, Ramón Corral, uno de los principales seguidores del régimen porfirista y simpatizante del afanoso monumentalismo, había sido contrincante y opositor de Ignacio Pesqueira, ${ }^{36}$ en honor a

tomo 1795) y a Benito Juárez, en Chihuahua en 1906 (AGES: fondo Ejecutivo, tomo 2129), a Sebastián Lerdo de Tejada en la Rotonda de los Hombres Ilustres en 1893 (AGES: Prefecturas, tomo 682).

34 Por ejemplo, en el discurso periodístico en relación con el fomento que se le dio a la construcción de estatuas en el Paseo de la Reforma, Díaz dijo: “No sólo impulsaría el arte escultórico de México, sino que contribuirá muy eficazmente a fomentar en los ciudadanos el noble estímulo para hacerse acreedores en el porvenir a la honra que se discierne, levantándoles estatuas a los que por sus virtudes cívicas, por su ciencia o por sus obras, merecen que su memoria sea perpetuada en un monumento artístico" (Zarate 2003: https://nuevomundo. revues.org/214).

36 Debe recordarse que Ramón Corral era redactor y editor de los periódicos locales, El Fantasma y LaVoz de Álamos, en la década de 1870, ambos medios fueron críticos y estaban en contra del 
quien ahora ordenaba la creación de una de las estatuas, para que se colocara en el Paseo de la Reforma y su réplica en el Palacio de Gobierno de Sonora. Este tipo de acciones repercutían en el imaginario de la época. ${ }^{37}$

Otro ejemplo similar de ejercicio del poder es el proceso de sacralización en el que se reconoce a los héroes del pasado, convertidos con el tiempo en epónimos de la reforma y del México político moderno. De esta forma se realiza un homenaje en doble sentido, del mero reconocimiento se pasa a lo implícito, se trata de alinear el pasado con el presente, en cuanto a que los propios gobernantes y Díaz se ligan a estos héroes como sus herederos. En este caso, Corral y el grupo porfirista como los legítimos sucesores renovados. ${ }^{38}$

El Estado porfirista como grupo de poder se perfila así como una entidad institutora, que actúa como el principal generador de creencias, mitos y valores dirigidos hacia las colectividades; un elemento propio de las representaciones sociales (Rodríguez 2003, 117-132). Asimismo, el Estado es el fundador y el encargado de escoger a sus héroes y personajes que sean dignos de reconocer y honrar en la memoria colectiva. Lo cual se considera como un ejercicio de poder en el que el Estado impone y disuade a las colectividades con fines propios. $^{39}$

gobernador y general Ignacio Pesqueira, por lo que tales acciones de Corral produjeron su persecución por parte de Pesqueira (Uruchurtu1984, 22). Por otro lado, en la memoria e imaginario colectivo de la elite porfirista regional, Ramón Corral figuraba como el hombre necesario que luchó contra el viejo régimen, por ejemplo, en el banquete que se ofrece en honor a Ramón Corral celebrado en el Hotel Arcadia, el 9 de noviembre de 1904, Aurelio D. Canale menciona en el brindis a Corral como un hombre "brillante [...] escritor público de 1875; político laborante y sagaz en 1882 que cooperó activamente a la demolición de un gobierno patológico [...]” (García 1905-1907).

37 Según Baczko, el potencial simbólico de los imaginarios agencia sentidos, y genera percepciones en la psique de los sujetos. El uso, desuso, apropiación y reapropiación permite la construcción del imaginario $(1991,56)$. En dicho caso, la vindicación de Pesqueira por parte de Corral marcaba una exacerbado reconocimiento como patriota y garante de lo que el mismo Corral ahora presentaba, es decir, los atributos morales y cívicos de un líder. Esto también se hace evidente en la reseña histórica en la que se incluye una biografía que Corral hizo en honor a Pesqueira (Uruchurtu 1984, 25). Por lo tanto, gran parte del culto a Pesqueira como héroe de la tradición liberal fue obra de su contrincante Ramón Corral.

38 Este fenómeno se dio de igual forma con el caso de Díaz hacia Benito Juárez, con la construcción del hemiciclo a Juárez en la Alameda (Lempérière 1995, 325).

39 Cabe destacar que la independencia era un acontecimiento que ya había sido retomado por la historiografía de los triunfadores de la república restaurada, de igual forma le dieron 


\section{Apoteosis local: crónicas inmortales de 1910}

Los rituales apoteósicos fueron algunas de las manifestaciones del ejercicio del poder político, en un contexto donde convivía el pueblo, lo colectivo y los grupos de poder, la elite y los gobernantes. ${ }^{40}$ Cuando se habla de apoteosis se hace referencia al ensalzamiento, las alabanzas y la honorificación por los clásicos, que al aplicarlos a héroes, emprendedores y otros mortales dignos de ocupar un lugar en la inmortalidad histórica, los coloca junto a los dioses clásicos.

De ahí que se retomen los rituales cívicos patrióticos, en específico los festejos del centenario, los cuales son analizados desde la perspectiva de la invención de la tradición de Hobsbawm, y con base en su propuesta se sugiere que dichos acontecimientos perpetúan una continuidad con el pasado a través de ciertos rituales, con el fin de generar un conciencia patriótica y nacionalista colectiva, y con miras a enaltecer el propio régimen porfirista.

Hobsbawm $(2002,8)$ concibe la invención de la tradición como el grupo de prácticas, gobernadas por reglas abiertas o tácitas, y de naturaleza simbólica o ritual, que buscan inculcar determinados valores o normas de comportamiento por medio de su repetición, lo cual implica continuidad con el pasado. Las tipologías formuladas por Hobsbawm son:

a) las que establecen o simbolizan cohesión social o pertenencia al grupo, ya sean comunidades reales o artificiales; b) las que es-

gestación al mito fundacional del "grito de independencia" en 1810, con Hidalgo como el "padre de la patria" e incitador de las ideas liberales que fomentarían la reforma (Hale 1995, 20-29). Quien habría de darle continuidad a ello sería Justo Sierra, como secretario de Educación y el propio Riva Palacio con su obra México a través de los siglos, donde presentaba de nuevo a la independencia como mito fundacional de la nación (Florescano 2001b, 63).

40 En la elite porfirista en Sonora es posible encontrar a una diversidad de empresarios, profesionistas, hacendados e industriales que destacan en una variedad de lazos, clientelas y relaciones con el gobierno, el cuatorvirato, que tuvo un afianzamiento político de varios años con personajes como Luis E. Torres, Rafael Izábal, Francisco Gándara y Ramón Corral. Ellos promovieron el llamado progreso porfirista que se vería materializado con la guerra contra "el yaqui", el desarrollo urbano, obras de infraestructura como el ferrocarril, pero sobre todo el fomento del nacionalismo. Esto se evidencia en el Álbum-directorio de Federico García y Alva, un texto que promovía a Sonora como una región de bondades y desarrollo alcanzado; se describe a su elite y la participación de ésta en el ámbito comercial, industrial e inclusive en el exterminio de los grupos étnicos vistos como la barbarie. 
tablecen o legitiman instituciones, estatus o relaciones de autoridad, y c) las que tienen como principal objetivo la socialización, el inculcar creencias, sistemas de valores o convenciones relacionadas con el comportamiento $(2002,16)$.

Las tres tipologías se encuentran ligadas al ejercicio del poder en distintos aspectos; la primera se relaciona con el nacionalismo, por medio de la identidad y la invención de una nación, en este caso propagado o representado a partir de elementos visuales tangibles, como la escultura de próceres patrios y la nomenclatura de las calles. La segunda se asocia con la creación e inauguración de recintos arquitectónicos que emblematizaban al Estado, como el Palacio de Gobierno, el Palacio nacional, la penitenciaría del estado y el cuartel del Catorce en Hermosillo. La tercera se vincula con los festejos de la independencia, en el sentido de que promueven el patriotismo, además de recrear el imaginario a partir de un mito fundacional.

En Hermosillo los rituales cívico-patrióticos eran de distinta índole, por ejemplo solían ser la llegada de algún gobernante, el ascenso de éste, la conmemoración de algún evento como el 5 de Mayo o la independencia, cuyos festejos datan de 1850, que solían realizarse cada 15 de septiembre por la noche en la Plaza de Armas, a donde acudía una población tumultuosa con antorchas encendidas para dar la voz de grito (Galaz 1996, 552).

Con la entrada del grupo porfirista este tipo de festejos siguió vigente, por ejemplo en 1880 se pronunciaban dos discursos, uno el 15 y otro el 16 de septiembre, por parte de algún orador, después se ofrecía un baile en la plaza de la Moneda o Pesqueira (Escobosa 1995 , 46). A estas festividades se fueron añadiendo más, por ejemplo, en 1909 se sumó la creación de obra pública, por lo que se aprovechaba el marco de tales fechas para inaugurarla, como sucedió con el paseo de caracol en el cerro de la Campana, una especie de camino con dirección a la cumbre, creado bajo la dirección del ingeniero Tomás Fregoso. También se abrían espacios de recreación, como carreras de caballos para la población, como una carrera de carruajes hacia la punta de este mismo cerro, por el camino de caracol (Galaz 1996, 516).

En 1910 se conmemoraría un centenario de la independencia, por lo que el fervor era más fuerte en comparación con el de las ce- 
lebraciones anteriores. ${ }^{41}$ Desde el centro del país se trataba de evocar un ideario colectivo, para que fuera notorio en las demás entidades. ${ }^{42}$ En la Ciudad de México se habían programado inauguraciones de edificios, paseos, monumentos y demás obra pública, a fin de resaltar el imaginario de progreso. ${ }^{43}$ Este modelo fue retomado de las festividades en París con L’Exposition Universelle á $1889 .{ }^{44}$

Los festejos del centenario se hicieron notorios en las capitales de los estados, a través de la instauración de construcciones. Por ejemplo, en Guanajuato se edificó el mercado Hidalgo; en Guadalajara, el monumento a la Independencia; en Yucatán se creó el zoológico El Centenario; en Hermosillo ${ }^{45}$ hubo algunas mejoras: la instalación de candelabros para lámparas en la plaza Zaragoza, la construcción de la calzada Centenario, la colocación de la primera piedra del monumento a Hidalgo y del mercado municipal "Luis E. Torres" y la inauguración de una fuente (calle Orizaba). ${ }^{46}$ Asimismo, se instaló un asta para la bandera en la plaza Zaragoza y se inauguró la escuela Leona Vicario, la cual al mismo tiempo fue sede del primer día de

41 En Sonora, desde abril de 1908 se hizo patente la preocupación por escoger delegados que presidieran una comisión pro festejos del centenario, la cual para mayo y agosto del mismo año ya estaba conformada por personajes como Felipe Salido, Filomeno Loaiza, Taide López y Celedonio Ortiz (Анан: caja 35, tomo 5. Comunicados del 8 de abril al 16 de agosto de 1908).

42 Por ejemplo, se fomentaba la creación de comisiones que estuvieran conformadas por entusiastas notables, que se hicieran cargo de presidir los festejos del centenario (AHAH: caja 35, tomo 5. Invitación a formar la Comisión del Centenario. 22 de marzo de 1908).

43 En la Ciudad de México se realizó un programa en el que durante todos los días de septiembre de 1910 hubiera festividades, recepciones, conmemoraciones, inauguraciones de instituciones, monumentos, edificaciones, así como otro tipo de eventos que propiciarían el prestigio internacional y el reconocimiento de México como una nación unida e importante (García 1911).

44 Este planteamiento va en el sentido de que a las fiestas en la Ciudad de México se invitó a una gran cantidad de representantes extranjeros, además de un cuerpo diplomático de 51 países, que incluían potencias mundiales como Estados Unidos, Francia, Inglaterra y Alemania. De este modo tras la creación de obra pública y de los rituales cívico-patrióticos, el país figuraría en el concierto de las otras naciones como un México moderno (Berkstein 2004, 82; Tenorio 1998, 13-17).

45 En Sonora están algunas obras, como la Casa Municipal y la cárcel en Etchojoa, la escuela de niñas Bárbara Ceballos en Álamos, un kiosco en la Plaza de Armas de Guaymas, mientras que en Altar se inauguró un depósito de agua y un jardín en la plaza, así como mejoras al kiosco (AGES: tomo 2583, expediente s/núm. octubre de 1910).

46 El proyecto original comprendía una fuente de cemento, con un surtidor artístico de bronce que representaba una amazona con un cuerno de la abundancia. Sin embargo, las crónicas señalan que la figura era de un tritón (AGES: fondo Ejecutivo, tomo 2583, expediente s/núm. 8 de octubre de 1910 y Galaz 1996, 516). 
clases, pues así lo había dispuesto Luis E. Torres. ${ }^{47}$ Además, se plantearon otros proyectos que no se llevaron a cabo. ${ }^{48}$

Este tipo de mejoras se sumaban a los eventos o, cuando menos, se incluían en el programa de los festejos; se emprendían a través de organizaciones, como las juntas patrióticas, presididas por personajes respetados en la sociedad y notables de la época. ${ }^{49}$ Éstos se daban a la tarea de sugerir proyectos que se tradujeran en mejoras materiales para la ciudad (construcción, rehabilitación de algún espacio o edificio), a la honra patriótica de algún personaje o conmemoración cívica, como sucedió con los festejos del centenario en Hermosillo. Para llevarlos a cabo buscaban las formas de alentar y conseguir el financiamiento del estado, la iniciativa privada o pública (Galaz 1996, 313). Después de la inauguración de la escuela Leona Vicario se efectuó un recorrido en carruajes, berlinas y carretas por las calles de la ciudad, donde se ondeaban banderas nacionales. Una especie de reconocimiento a los propios grupos de poder. Esta comitiva estaba conformada por personajes destacados de la época como Luis E. Torres, Rafael Izábal, Alberto Cubillas, Aurelio D. Canale, Guillermo Domínguez y Tomás Fregoso, entre muchos más (Galaz 1996, 353).

Por la noche se dio el grito de independencia en la Plaza de Armas, al llegar a este punto la multitud que venía de las distintas zonas de la ciudad podía observar la majestuosidad de la luz eléctrica en la plaza, puesto que el kiosco se encontraba adornado con luces, el palacio de igual forma contenía centenares de foquillos en los dos pisos, balcones y cornisas, que le daban una imagen de residencia palatina. Mientras que la plaza contaba con algunos alumbrados arbotantes, es decir, estructuras de arcos iluminados (Galaz 1996, 353).

47 AGES: fondo Ejecutivo, tomo 2583, expediente s/núm. Noticias de las mejoras materiales inauguradas con motivo de la conmemoración del centenario de independencia. 8 de octubre de 1910 .

48 La colocación de relojes en algunos edificios públicos, los cuales serían inaugurados con motivo de los festejos y se incluirían en el programa. Esta petición fue hecha por la Junta de Mejoras Materiales al gobierno del estado, en contestación éste precisa no poder brindar tal apoyo a "tan noble y patriótico proyecto" (AGES: tomo 2583, expediente s/núm. 4 de febrero de 1910).

49 Por ejemplo, para las mejoras del parque Ramón Corral, en 1901, participaron Manuel D. Loaiza, Manuel R. Uruchurtu, Ernesto Camou y Alberto Cubillas. En la construcción del parián y las mejoras del palacio municipal, en 1879, colaboraron Rafael Izábal, Carlos Nanetti, Enrique Monteverde, Felizardo Torres y Víctor Aguilar, entre otros. 
La luz eléctrica jugó un papel fundamental durante estos festejos, pues sus adornos dotaron de belleza y atracción visual al paisaje haciendo de la Plaza de Armas un teatro donde los protagonistas eran los héroes representados en figuras, ${ }^{50}$ así como los gobernantes que reafirmaban su poder al situarse en el balcón y dar el "grito" de independencia. De esta forma se ligaba el pasado con el presente, por medio del mito fundacional de independencia; ahora el gobernante porfirista se hacía acreedor a la herencia. La usanza del balcón para la presentación y reconocimiento del dirigente estaba incorporada a este ritual, bajo el supuesto de que se reforzaba el ejercicio del poder en un sentido simbólico. ${ }^{51}$

El grito de independencia estuvo ataviado con cohetes, la diana de la banda y el repique de las campanas. Al día siguiente se llevó a cabo un desfile militar, compuesto por un pelotón de caballería, con bandas de guerra, de una tropa de infantería del cuerpo de rurales del onceavo batallón. Para darle más majestuosidad a la celebración usaron una indumentaria vistosa, así como cajas de carreta tiradas con mulas, exhibiendo sus armas, balas de cañón y ametralladoras de cintas (Galaz 1996, 355). Este ritual, de acuerdo con las tipologías de Hobsbawm, remarca la segunda etapa, en el sentido de que con este desfile se legitimaban las instituciones de poder de la época: el Estado y el Ejército, a la vez que se establecía una relación de autoridad. Los militares eran aplaudidos a su paso. Así, a través del Ejército, las bandas de música, los edificios y el pueblo se daba una impresión “de poderío y fuerza" (Galaz 1996, 355). Otro ejemplo notable en la región, y similar al de Hermosillo, fue el de Álamos. ${ }^{52}$

Galaz se refiere a las figuras de Porfirio Díaz y Miguel Hidalgo ardiendo [en sentido figurado] en la plaza $(1996,354)$.

51 Albert Elsen refiere en una de sus obras al potencial simbólico de los balcones para el ejercicio del poder, argumenta, que en un sentido funcional, el modo en el que se priva a ventanas y columnas, cuando se les subordina al efecto total. Así como el uso de las zonas recesivas sobresalientes y estrechas en las secciones intermedias de las edificaciones contribuyen a enfocar la atención sobre el balcón central. Bajo el mismo supuesto, para Bernini es también un símbolo arquitectónico de autoridad centralizada (1978, 41-42).

52 En Álamos, además del grito de independencia, el alcalde ofreció una serie de eventos el 14, 15 y 16 de septiembre, los cuales incluían serenatas, procesiones cívicas, ceremonias, discursos, lectura del acta de independencia, inauguraciones de escuelas, bailes y hasta una carrera de caballos (AGEs: fondo Ejecutivo, tomo 2583, expediente s/núm. Programa de los Festejos del Centenario en Álamos). 
Lo que refieren este tipo de conmemoraciones es que los rituales tejen formas elementales de sociabilidad en una comunidad, ya que el espectáculo y la cultura política que promueven encierran persuasión, cuando en la pompa de las ceremonias cívicas se crean espacios de unanimidad alrededor de símbolos, emblemas e imágenes de representación estatal. También fomentan la coerción, porque permiten la puesta en escena de los imaginarios del poder (González 1998, 8; Brenes 2004, 114).

Los festejos del centenario en Hermosillo reflejaron un ejercicio de poder, a través de dispositivos simbólicos de las instituciones del Estado, con el objetivo último de generar un comportamiento deseable, mediante el fomento de una tradición cívico-patriótica a fin de mantener y legitimar el régimen porfirista en la localidad. Por ejemplo, el mero referente de la independencia subrayaba la premisa fundamental del discurso nacionalista del régimen remarcando que México había nacido en 1810 como nación independiente, y que a partir de esa fecha se había iniciado una marcha de evolución constante hacia 1910, por lo que quien se encontraba en el poder en ese momento era el acreedor de dicho discurso (Brenes 2004, 112).

\section{Consideraciones finales}

A partir de lo expuesto, es posible afirmar que la estructura espacial de Hermosillo durante el porfiriato presenta una red panóptica, en la que se conjugan elementos disciplinarios como la nomenclatura de sus calles y corredores, que bajo una lógica de poder somete a la sociedad y recrea un sentido de persuasión, con símbolos y signos del nacionalismo, patriotismo y culto a los héroes, a fin de hacer patente el ideario del régimen. Contempla entre transeúntes y habitantes la idea de pertenencia, a través de la cohesión e imaginarios del porfiriato, "la nación y los héroes que nos dieron patria", la reforma y la independencia. En lo referente al cariz que adquirieron dichas acciones, es posible observar que el propósito era instaurar la infraestructura de una ciudad funcional, en relación con su ordenamiento, y fomentar simultáneamente la intensificación de los sentimientos cívicos y patrióticos; implementar proyectos de este tipo era otra forma de "educar" a los ciudadanos. 
Las tres estatuas en Hermosillo reforzaron el elemento histórico haciéndolo público, y resaltaron así a los héroes distinguidos, de los que se sirvieron los grupos hegemónicos regionales para legitimar su ascenso y permanencia en el poder. ${ }^{53}$ Se trataba de preservar la memoria histórica, la cual era un medio para la gestación de la identidad nacional. El Estado porfirista -como grupo de poder-se perfiló como una entidad institutora, generadora y promotora de creencias, mitos héroes y valores dirigidos hacia la colectividad.

Por otro lado, los rituales cívico-patrióticos representan la culminación del ejercicio del poder del régimen, pues es donde se conjuga la totalidad de los medios visuales tangibles o los mecanismos de coerción, que se habrían creado a la usanza del espacio urbano como escenario de éstos. Cada administración pública imprime su toque y ejercicio del poder, como ocurrió en las calles de Hermosillo que al entrar el movimiento de la revolución cambiaron de nombre, a fin de resignificar el espacio público. Por ejemplo, las que tenían algún referente del porfiriato, como la de Don Luis, cambió a Aquiles Serdán, el primer mártir de la revolución, al igual que la de Porfirio Díaz que cambió a Vázquez Gómez. ${ }^{54}$ Hubo una reapropiación ideológica del espacio, el nuevo grupo de poder imprimía su toque en el espacio urbano al borrar la historia y reimprimir una nueva, que justificara el ascenso de los nuevos gobernantes.

Recibido en junio de 2014 Aceptado en octubre de 2014

\section{Archivos}

Archivo General del Estado de Sonora.

Archivo Histórico del Ayuntamiento de Hermosillo.

Sistema Nacional de Fonotecas, Instituto Nacional de Antropología e Historia (INAH Pachuca): Colección Sonora.

53 Como el político porfirista Ramón Corral en relación con la figura de Ignacio Pesqueira.

54 AGES: tomo 2701, fondo Ejecutivo. 26 de junio de 1911. 
Mapoteca Orozco y Berra: Colección Sonora, varillas CGSON.

\section{Bibliografía}

Anderson, Bendedict. 1993. Comunidades imaginadas. Reflexiones sobre el origen y la difusión del nacionalismo. México: Fondo de Cultura Económica (FCE).

Agulhon, Maurice. 1994. Historia vagabunda. Etnología y política en la Francia contemporánea. México: Instituto Mora.

Baczko, Bronislaw. 1991. Los imaginarios sociales. Memorias y esperanzas colectivas. Buenos Aires: Nueva Visión.

Banchs, María A., Álvaro Agudo Guevera y Leslie Astorga. 2007. Imaginarios, representaciones y memoria social. En Espacios imaginarios y representaciones sociales. Aportes desde Latinoamérica, compilado por Denise Jodelet y Denise, Túnico Amancio, 47-99. España: Antropos Editorial/ Universidad Autónoma Metropolitana (UAM) Iztapalapa.

Barthes, Roland. 1990. La aventura semiológica. Barcelona: Paidós.

Berkstein Kanarek, Celia. 2004. La concepción simbólica del poder: el Palacio Legislativo federal porfiriano. Historia y Grafía (22): 79111.

Bobbio, Norberto. 1982. Diccionario de política. México: Siglo XxI.

Bonet Correa, Antonio. 1980. La arquitectura de la época porfiriana. México: Instituto Nacional de Bellas Artes.

Brading, David. 1980. Los orígenes del nacionalismo mexicano. México: Ediciones Era.

Brenes Tencio, Guillermo. 2004. Héroes y liturgias del poder: la ceremonia de la apoteosis. México, 6 de octubre de 1910. Ciencias Sociales IV (106): 107-121. 
Carrasco, Francisco J. 1876. Al Ayuntamiento. La Regeneración. 21 de junio.

Castoriadis, Cornelius. 2004. Sujeto y verdad en el mundo histórico social. Argentina: FCE.

Choay, Françoise. 1965. Urbanisme: utopiesetréalités. París: Editions du Seuil.

De la Torre Villar, Ernesto. 1986. Historia documental de México. México: Universidad Nacional Autónoma de México (UNAM).

Elsen, Albert Edward. 1978. La arquitectura como símbolo de poder. Barcelona: Tusquets.

Escobosa Gámez, Gilberto. 1995. Hermosillo en mi memoria. Hermosillo: Instituto Sonorense de Cultura.

Fernández Christelieb, Federico. 2000. Europa y el urbanismo neoclásico en la Ciudad de México. Antecedentes y esplendores. México: Plaza y Valdés.

Florescano, Enrique. 2001a. La bandera mexicana. México: Taurus.

Florescano, Enrique. 2001 b. El nuevo pasado mexicano. México: Cal y Arena.

Foucault, Michel. 2000. Nietzsche, la genealogía, la historia. Valencia: PreTextos.

Foucault, Michel. 1991. Vigilar y castigar. Madrid: Siglo XXI.

Foucault, Michel. 1986. Vigilar y castigar. Madrid: Siglo XXI.

Foucault, Michel. 1980. The eye of the power: conversation with J-P Barou and M. Perrot. En Power/knowledge: selected interviews and other writtings, 1972-1977. Nueva York: Harvester Press.

Foucault, Michel. 1979. Microfísica del poder. Madrid: La Piqueta. 
Fourquet, François y Lion Murard. 1978. Los equipamientos del poder. Madrid: Gustavo Gili.

Galaz, Fernando. 1996. Dejaron huella en el Hermosillo de ayer y hoy. Hermosillo: Instituto Sonorense de Cultura.

García, Genaro. 1911. Crónica oficial de las Fiestas del Primer Centenario de la Independencia de México. México: Talleres del Museo Nacional.

García y Alva, Federico. 1905-1907. Álbum-crónica. De las fiestas efectuadas en Sonora en honor del señor vicepresidente de la república. Hermosillo: Talleres de imprenta. Encuadernación y rayados de Belisario Valencia.

Geller, Ernest. 2003. Naciones y nacionalismo. Madrid: Alianza.

Georg, Leidenberger. 2004. Proximidad y diferenciación: el manejo del concepto del espacio en la historiografía urbana. Historia y Grafía (22): 51-77.

González Pérez, Marcos. 1998. Fiesta y nación en Colombia. Santafé de Bogotá: Editorial Magisterio.

Guerra, François Xavier. 2012. México: del Antiguo Régimen a la revolución. México: FCE.

Hale, Charles. 1995. El liberalismo mexicano en la época de Mora, 1821-1853. México: Siglo XXI.

Hardoy, Jorge E. 1964. Ciudades precolombinas. Buenos Aires: Infinito.

Hobsbawm, Eric y Terence Ranger (editores). 2002. La invención de la tradición. Barcelona: Crítica.

Karp, Lían. 1992. Semblanza de Hermosillo a través de las crónicas. Hermosillo: El Colegio de Sonora.

Le Goff, Jacques. 1991. El orden de la memoria. El tiempo como imaginario. España: Editorial Paidós. 
Lefbvre, Henri. 1976. Espacio y política. España: Ediciones Península.

Lempérière, Annick. 1995. Los dos centenarios de la independencia mexicana (1910-1921): de la historia patria a la antropología cultural. Historia Mexicana XLV 178 (2): 317-352.

León, Maru. 2002. Representaciones sociales: actitudes, creencias, comunicación y creencia social. En Psicología social, coordinado por J. F. Morales, D. Páez, A. L. Kornblit y D. Asún, 367-385. Buenos Aires: Prentice-Hall.

Luján, José María. 1963. Entrevista Díaz - Creelman. México: Cuadernos del Instituto de Historia. Serie Documental número 2. México: UNAM.

Martínez Assad, Carlos. 2005. La patria en el Paseo de la Reforma. México: FCE.

Monsiváis, Carlos. 1992. Sobre los monumentos cívicos y sus espectadores. En Monumentos mexicanos. De las estatuas de sal y piedra. México: Consejo Nacional para la Cultura y las Artes, Grijalbo.

Moya Gutiérrez, Arnaldo. 2007. Historia, arquitectura y nación bajo el régimen de Porfirio Díaz. Ciudad de México 1876-1910. Revista Ciencias Sociales (117-118): 159-182.

Muguerza, Javier. 2000. Universalismo y multiculturalismo. El puesto del hombre en la cosmópolis. En Universalismo y multiculturalismo, compilado por María Julia Bertomeu, Rodolfo Gaeta, Graciela Vidiella y Osvaldo Norberto Guariglia, 159-161. Buenos Aires: Eudeba.

Munford, Lewis. 1966. La ciudad en la historia: sus orígenes, transformaciones y perspectivas. Buenos Aires: Infinito.

Nora, Pierre. 2009. Em les lieux de la memorie. España: Ediciones Lom. 
Pérez Salas, María Esther. 2010. Los arcos triunfales en las fiestas del centenario. Bicentenario. El ayer y hoy de México. 3 (9): 36-43. Instituto de Investigaciones Dr. José María Luis Mora.

Radley, Alan. 1992. Artefactos, memoria y sentido del pasado. En Memoria compartida. La naturaleza social del recuerdo y del olvido, compilado por David Middelton y Derek Edwards, 63-77. Barcelona: Paidós.

RAE. WWW.rae.es

Riva Palacio, Vicente. 1968. México a través de los siglos. México: Compañía General de Editores.

Rodríguez Cerda, Óscar. 2003. Entrevista a Denise Jodelet, realizada el 24 de octubre de 2002. Relaciones Estudios de Historia y Sociedad XXIV (93): 117-132.

Shávelzon, Daniel. 1988. La polémica del arte nacional en México, 1850-1910. México: FCE.

Sosa, Francisco. 1996. Las estatuas de la Reforma. México: UNAM.

Sierra, Justo. 2009. La evolución del pueblo mexicano. México: Editorial Porrúa.

Sierra Méndez, Justo. 1948. Evolución política del pueblo mexicano. En Obras completas, tomo XII. México. UNAM.

Tenenbaum, Barbara.1994. Streetwise history: the Paseo de la Reforma and the porfirian state: 1876-1910. En Rituals of rule of resistance. Wilmington: SRBOoks.

Tenorio Trillo, Mauricio. 1998. Artilugio de la nación moderna. México en las exposiciones universales, 1880-1930. México: FCE.

Tirado, F. J. y M. Mora. 2002. El espacio y el poder: Michel Foucault y la crítica de la historia. Espiral. Estudios sobre Estado y Sociedad 9: 11-36. 
Uruchurtu, Manuel. 1984. Apuntes biográficos de Ramón Corral, 1854-1900. Hermosillo: Gobierno del Estado de Sonora.

Vargas, Ramón. 1989. Historia de la teoría de la arquitectura. México: UAMXochimilco.

Vázquez, Josefina Zoraida. 1998. México al tiempo de su guerra con Estados Unidos, 1846-1848. México: FCE.

Weber, Max. 1998. El político y el científico. Madrid: Alianza.

Weber, Max. 1984. Economía y sociedad. México: FCE.

Wunenburger, Jean-Jaques. 2003. L'imaginarie. Collection Que Sais-Je. París: Presses Universitaires de France.

X. de Anda, Enrique. 1995. Historia de la arquitectura mexicana. España: Ediciones Gili.

Zamora Müller, Juan Carlos, 2003. Verdad, belleza y utilidad. Tres monumentos patrios del porfiriato. En Ensayando la historia, coordinado por Clara García Ayuluardo y Antonio Annino. México: Centro de Investigación y Docencia Económicas.

Zárate Toscano, Verónica. 2010. Los hitos de la memoria o los monumentos en el Centenario de la Independencia de México. Ópera imaginaria en una obertura y tres actos. Historia Mexicana LX (1): 85-135.

Zárate Toscano, Verónica. 2001. El lenguaje de la memoria a través de los monumentos históricos en la ciudad de México (siglo XIX). Nuevo Mundo Mundos Nuevos, materiales de seminarios: http://nuevomundo.revues.org / http://www.revues.org (5 de agosto de 2014). 


\section{Anexo}

\section{Figura 1}

Plano hablado de la ciudad de Hermosillo, 1835

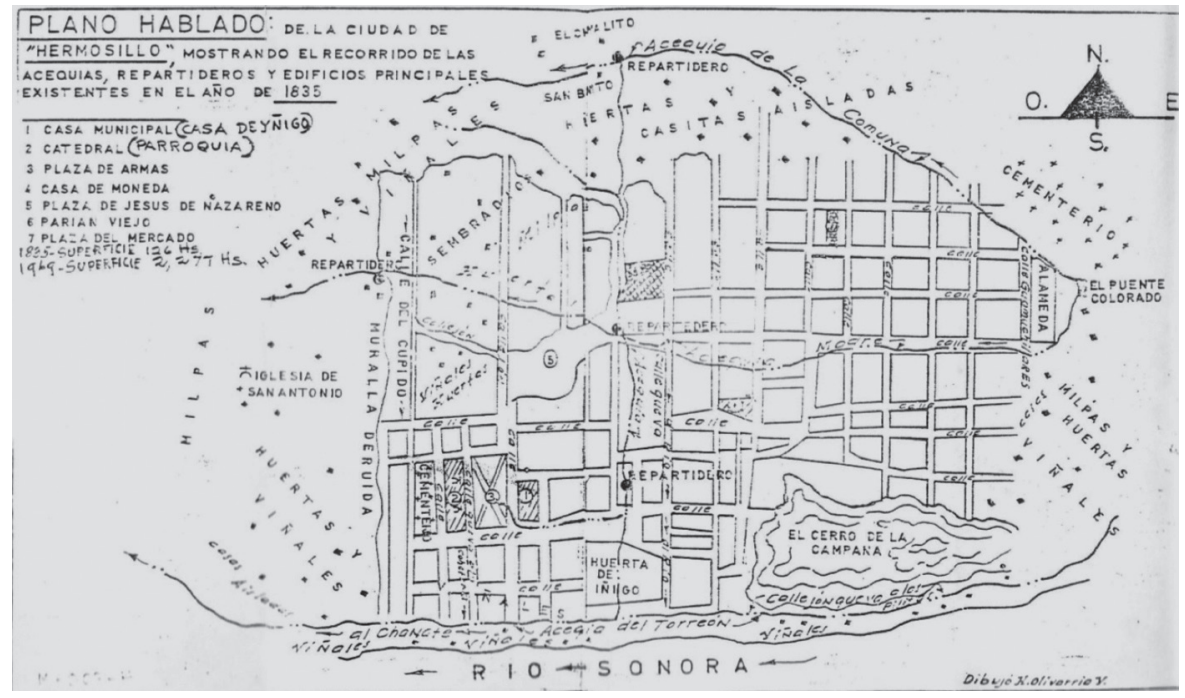

Fuente: mapoteca AGES, gaveta D.

\section{Figura 2}

Plano topográfico del fundo legal de Hermosillo, 1895; aparece la división de los trece cuarteles, así como las acequias de la ciudad

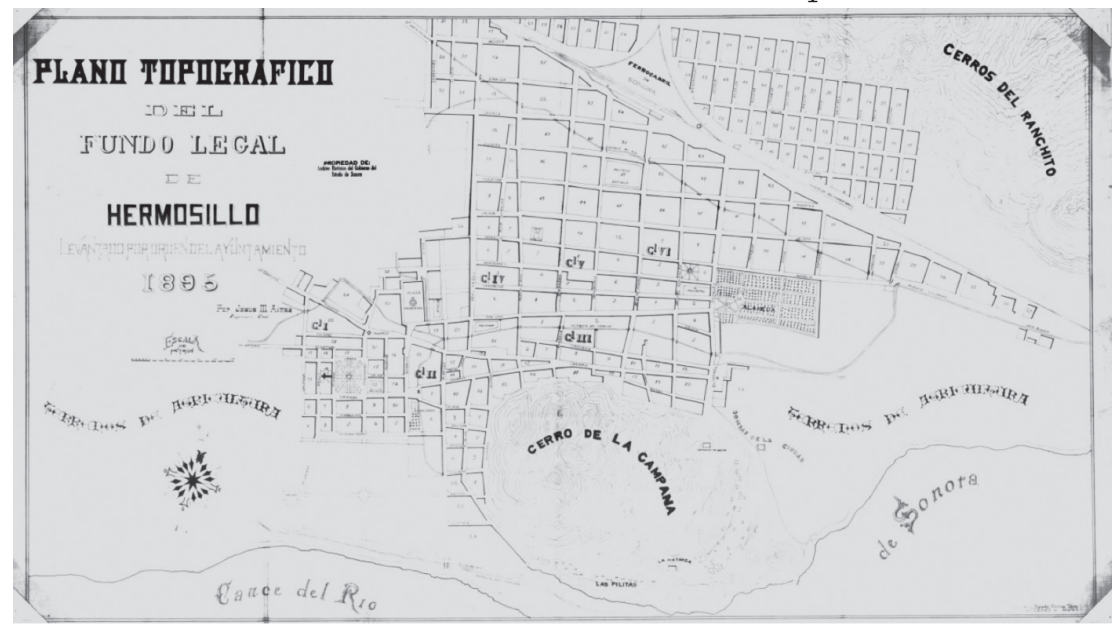

Fuente: mapoteca AGES, gaveta D. 


\section{Figura 3}

Plano topográfico del fundo legal de Hermosillo, 1900

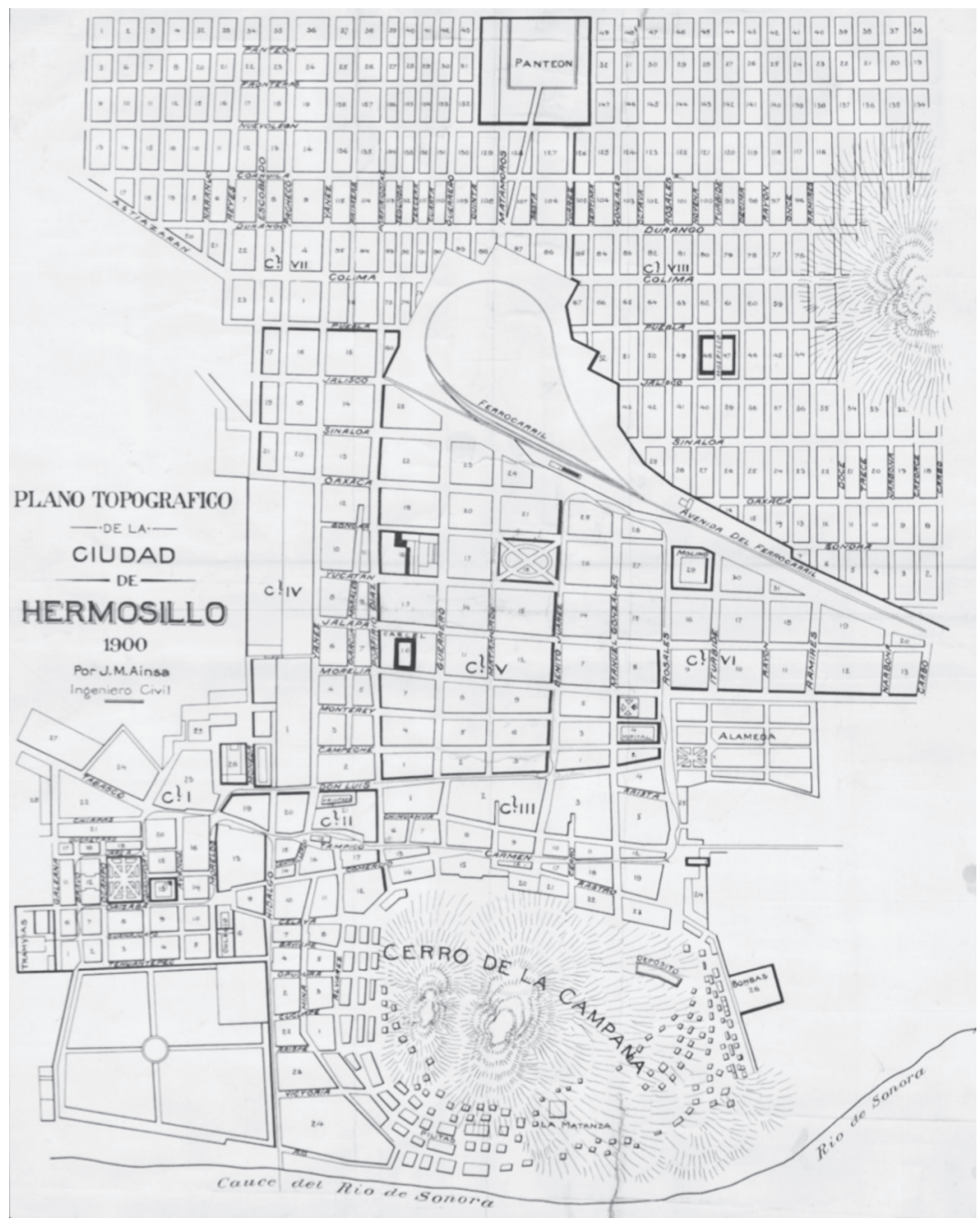

Fuente: mapoteca Orozco y Berra: Colección Sonora, varillas CGSON. 


\section{Figura 4}

Estatua del general Jesús García Morales en el Paseo de la Reforma

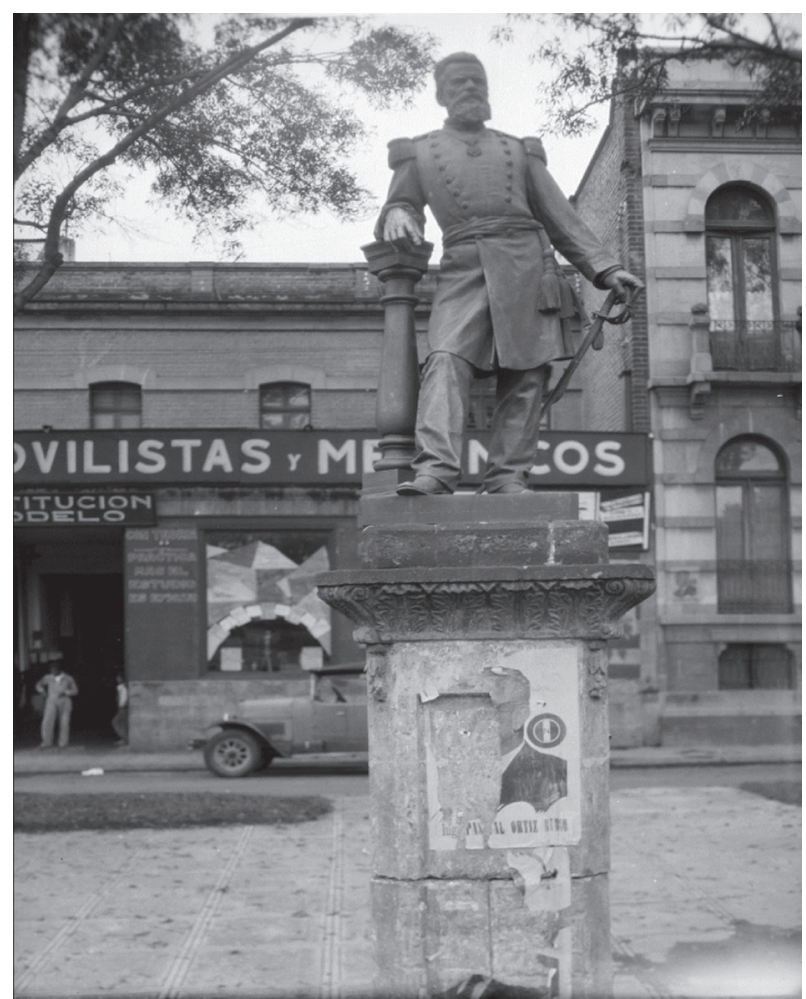

Fuente: fototeca INAH, Pachuca (título original: Monumento a Jesús García Morales, ubicado en el Paseo de la Reforma, inventario 2937). 


\section{Figura 5}

Estatua de Ignacio Pesqueira en el Paseo de la Reforma

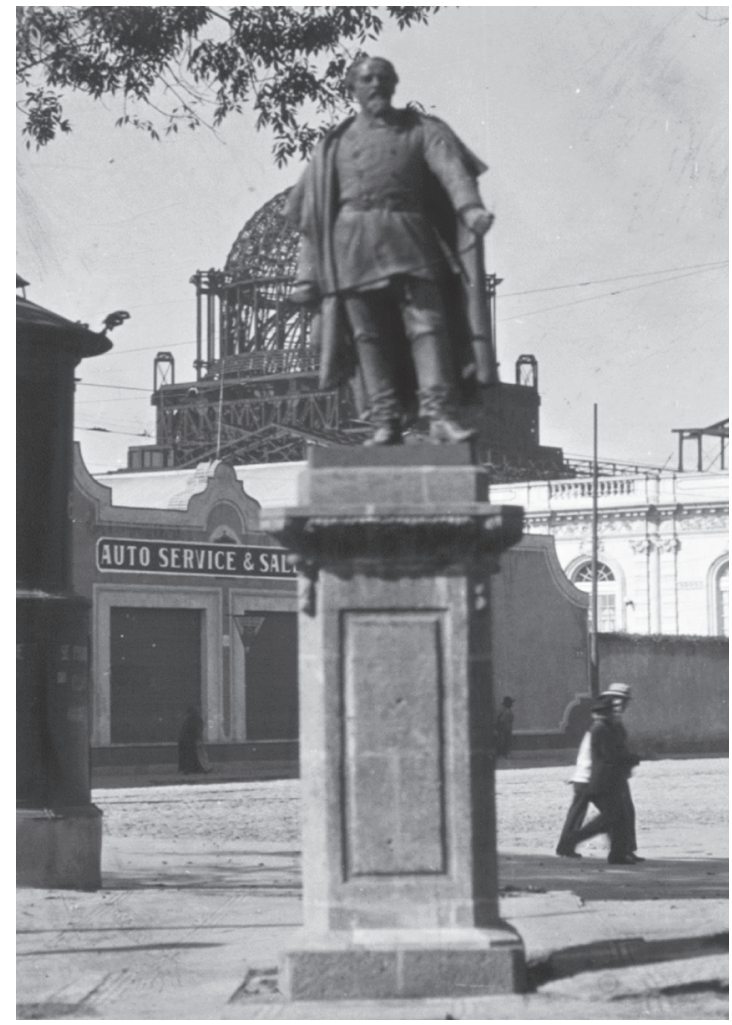

Fuente: fototeca INAH, Pachuca (título original: Monumento al general Ignacio Pesqueira, inventario: 164853). 


\section{Figura 6}

Estatuas de los generales Ignacio Pesqueira (izquierda), y Jesús García Morales (derecha) en el Palacio de Gobierno (Sonora)
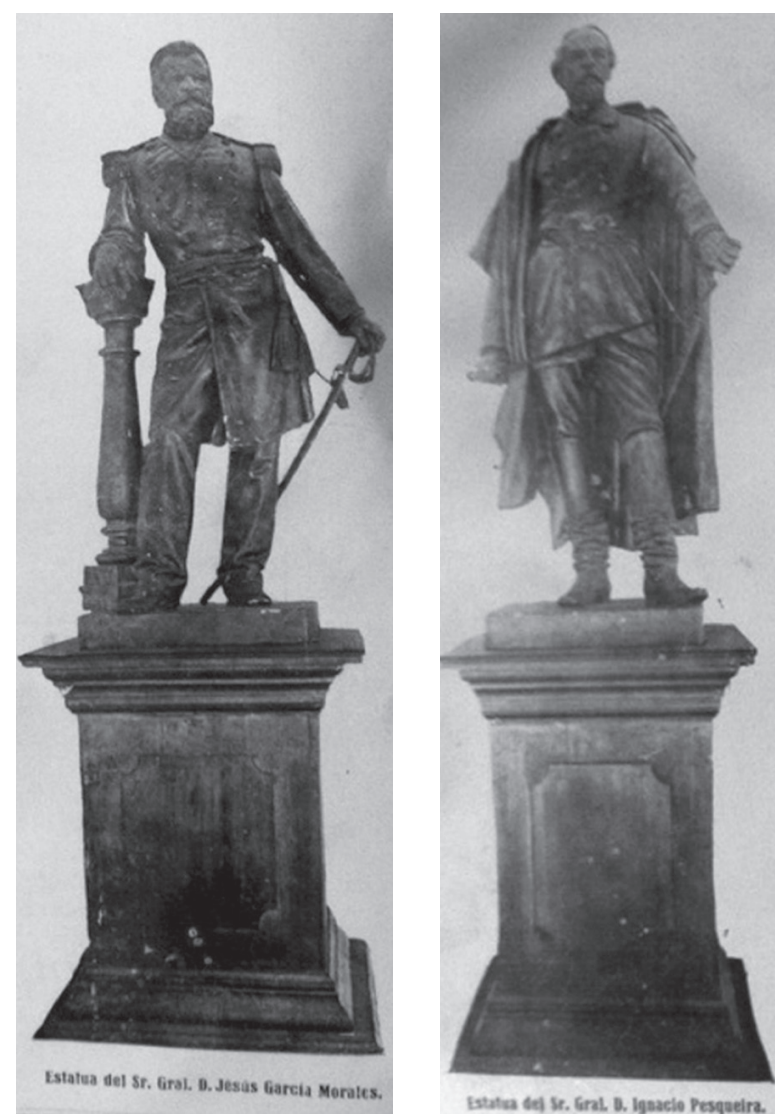

Fuente: García y Alva (1905-1907). 
